University of Wollongong

Research Online

Faculty of Social Sciences - Papers (Archive) Faculty of Arts, Social Sciences \& Humanities

2016

Living with landscape fire: Landholder understandings of agency, scale and control within fiery entanglements

Amanda Edwards

University of Wollongong, ae751@uowmail.edu.au

Nicholas J. Gill

University of Wollongong, ngill@uow.edu.au

Follow this and additional works at: https://ro.uow.edu.au/sspapers

Part of the Education Commons, and the Social and Behavioral Sciences Commons

Research Online is the open access institutional repository for the University of Wollongong. For further information contact the UOW Library: research-pubs@uow.edu.au 


\title{
Living with landscape fire: Landholder understandings of agency, scale and control within fiery entanglements
}

\begin{abstract}
Around the world, debates over how to manage and adapt to bushfires (or wildfires) are increasingly prominent as more and different people, many of whom have little or no experience with landscape fire or land management, inhabit fire-prone environments. But bushfire events represent only the most visible aspect of complex entanglements which operate across huge temporal and spatial scales and over which humans have very limited control. In this article, we focus on how Australian landholders of settler or migrant heritage understand scalar complexities and agency and control within human/landscape fire entanglements. In view of the fact that the learning styles of landholders new to rural areas have been developed in different environments with very different challenges, we also ask whether immersion within rural, fire-prone environments influences ways of 'knowing' land and fire.
\end{abstract}

\section{Keywords}

fiery, entanglements, control, scale, within, agency, living, understandings, landholder, fire, landscape

\section{Disciplines}

Education | Social and Behavioral Sciences

\section{Publication Details}

Edwards, A. \& Gill, N. (2016). Living with landscape fire: Landholder understandings of agency, scale and control within fiery entanglements. Environment and Planning D: Society and Space, 34 (6), 1080-1097. 
Living with landscape fire: landholder understandings of agency, scale and control within fiery entanglements

\begin{abstract}
Around the world, debates over how to manage and adapt to bushfires (or wildfires) are increasingly prominent as more and different people, many of whom have little or no experience with landscape fire or land management, inhabit fire-prone environments. But bushfire events represent only the most visible aspect of complex entanglements which operate across huge temporal and spatial scales and over which humans have very limited control. In this paper, we focus on how Australian landholders of settler or migrant heritage understand scalar complexities and agency and control within human/landscape fire entanglements. In view of the fact that the learning styles of landholders new to rural areas have been developed in different environments with very different challenges, we also ask whether immersion within rural, fire-prone environments influences ways of 'knowing' land and fire.
\end{abstract}

\title{
Introduction
}

In Australia, the USA and elsewhere, bushfires (or wildfires) burst into human consciousness by threatening, and sometimes consuming, life and property on a broad scale. Debates about how humans can manage and adapt to bushfires are increasingly prominent; for example, it has been stated that "No subject related to land management in Australia generates more heat or less light than fire" (Blake 2003:120, cited in Halliday et al 2012:206). These debates are complicated by the fact that, as rural demographics change, more and different people, many of whom have little or no experience with landscape fire or land management, are inhabiting fire-prone landscapes (Eriksen and Prior 2011). Moreover, the ways in which these people learn about land and fire management frequently differ, at least initially, from those of long-term inhabitants in rural areas. It has been suggested that these differences in learning styles are due, at least in part, to the "property centric" (Cooke and Lane 2015:46) orientation of relative newcomers which contrasts with the more social positioning of long-term farmers who have a "collective 
interest in maintaining productive rural landscapes" (2015:49, see also Eriksen and Prior 2011).

Unlike rural in-migrants, bushfire does not recognise property boundaries. And bushfire events themselves represent only the most visible aspect of complex entanglements which operate across huge temporal and spatial scales. These entanglements include, amongst a multitude of other actors, land topography, weather and climate, plant responses to stress, the persistence of weeds, human prescribed landscape fire, planning decisions, legislation and funding for emergency services. Traditionally, many indigenous peoples have maintained a relational ontology around fire that has evolved over millennia of co-existence and recognises the fragility of human control over fire events (see Head 1994, Gammage 2011, Langton 1998, Miller and Davidson-Hunt 2010, Verran 2002). Whilst paying some attention to Aboriginal relationships with fire, however, attempts within wider Australian society to develop new cultures to enable "co-existence with fire" (Howitt 2014) have tended to focus on the science of fire and fire management, the logics of planning and response and the building of ever more complex fire resources and institutions.

In recent years, academics informed by indigenous and other perspectives have called for debate, policy and practice to incorporate understanding of the broader relationships within which bushfire moves, swells and recedes (Griffiths 2009, Franklin 2006, Howitt 2014, Langton 1998, Maclean 2009, Williams 2014). In particular, concern has been expressed that wider Australian society is failing to get to grips with issues of scale (Griffiths 2009, Howitt 2014, Williams 2014) and the shifting patterns of control (Griffiths 2009, Howitt 2014) inherent within these relationships. This paper addresses these concerns by asking how landholders who "live the question" (Rilke, 1993: Letter 4) of how to coexist with the immanence of bushfire on a daily basis understand issues of scale, agency and control in this context. In view of the potential clash between the reported property-centric orientation of recent in-migrants and the massive temporal and spatial scales influencing fiery entanglements, we question whether landscape fire and its associated relationships can be active agents in the development of understandings of scalar complexities. We also ask how dwelling in an environment in which, as one reviewer of this paper wrote, "physical agencies and dynamisms are often brutally insistent", influences understandings of control within human/nature relationships. Finally, we consider whether immersion in fire-prone 
environments influences the learning styles of in-migrants which have developed in different environments with very different challenges.

These topics have received very limited attention up to now. Extensive research has been conducted into the relationships between fire, land and Aboriginal peoples including those living traditionally and those whose lifestyles have been fundamentally disrupted by the 'modernisation' of Australia (see e.g. Gammage 2011, Haynes 1985, Head 1994, Jones 1969, Langton 1998, Russell-Smith et al 2002, Vaarzon-Morel and Gabrys 2009). Comparisons have been made between the burning practices of Aboriginal landholders and managers and 'modern' scientists (Verran 2002), and between Aborigines and pastoralists (MacLean 2009). Opinions have been sought from landholders of settler heritage on Aboriginal burning (MacLean 2009) and the burning of publicly owned land (Gill 1994). Yet whilst research has been undertaken into how landholders of settler heritage perceive wildfire risk (Eriksen and Prior 2011) and, more broadly, what they know and do about and with fire (Halliday et al 2012), we have been able to find no research which explicitly allows these landholders to voice their understandings of spatio-temporal scales, complexity and control within human/fire/land entanglements. Furthermore, whilst previous research (Eriksen and Prior 2011) suggests a shift in landholder relationships with landscape fire over the first decade of owning a rural property, there has been limited inquiry into the processes involved in this shift.

It is important to address these gaps for two main reasons. Taking seriously the proposal to move beyond an "undifferentiated, colonial sense of the "bush"' (Griffiths 2009:35.5) in developing new fire cultures requires that we pay detailed attention to situated, eco-social relationships. Empowering local residents and their ecological knowledge requires that we first understand their relationships with fire and the processes by which relationships and knowledge evolve.

Secondly, from a pragmatic perspective, private landholders are increasingly being co-opted into landscape scale plans to enhance community safety and environmental values such as biodiversity and water quality (Lockie and Higgins 2007). The 'shared responsibility' approach recommended by the Victorian Bushfires Royal Commission (2010:352) and adopted by fire-fighting organisations across Australia expects that landholders actively 
manage their land to reduce risks of bushfire to people, property and the wider environment. Understanding how landholders conceptualise their relationships with fire will provide insight into their likely willingness to be co-opted into these landscape scale projects and the most appropriate approach to outreach and education.

\section{Notes on Terminology}

Throughout this paper we use the term "fiery entanglements" to describe the socio-bio-geophysical complex which incorporates prescribed fire and bushfire, the abiotic environment, including topography, weather and rocks, living organisms such as humans, other animals, plants and fungi and human social, political and cultural relationships. We use this term to highlight interdependencies and dynamic interrelationships and the fact that each apparently separate 'element' within these entanglements cannot be isolated nor extricated without affecting the whole (see Ingold 2008).

\section{"Country" is another term which draws attention to interdependencies and} interrelationships. In this paper it is used not in the sense of a nation or state with its own government (Hsu et al 2014:370) but rather goes beyond land and / or government to incorporate "social, environmental and cosmological relations" (Hsu et al 2014:371). Thus, we use the term in the sense outlined by Bawaka Country inc. (2013:371), in which Country "encompasses humans as well as waters, seas and all that is tangible and non-tangible and which become together in a mutually caring and multi-directional manner to create and nurture a homeland" (Bawaka Country inc. 2013:186). Originally an Australian Aboriginal concept, Country implies ideas of embeddedness and belonging and, as such, its appropriation by settler Australians has political implications. Whilst we cannot speculate on its use by landholders within our research, we occasionally use this term ourselves in a respectful attempt to move beyond 'human / nature' dualisms and recognise the multiple, multi-directional, more-than-human relationships involved in fiery entanglements.

The word "agency" has multiple meanings, some of which are concerned with the moral will or intentionality of individual human subjects and others with the powers expressed by 'proto-bodies' (Bennett 2010:29-31). It is beyond the scope of this article to delve too 
deeply into this discussion, hence a relatively simple definition will suffice in which agency is seen as "the capacity to make something new appear or occur" (Bennett 2010:31).

We use the term "non-human" rather than the more cumbersome "other-than-human" despite the fact that 'non-human' can appear to deny 'human / nature' interdependencies. Whilst many of the relationships within contemporary Australian fiery entanglements are influenced by human driven processes, some, such as the current position of Australia within broad climatic zones, and notwithstanding anthropogenic climate change, are not. Rather than tie ourselves in lexical knots we use the term 'non-human' but do so with the view that the 'non-human' is rarely entirely not human (see Bawaka Country Inc. [2013:189] for a discussion of the challenges of using the English language to express relational ontologies).

\section{Unbounding Fire}

Landscape fire has been the subject of several environmental histories that reach back millions of years to describe the northern migration of Australia away from its Gondwanan relations, its leaching, drying and increasing susceptibility to fire, and the shift in vegetation from rainforest to sclerophylly (Franklin 2006, Griffiths 2001, Pyne 1998). Scholars dwelling on more recent history (Flannery 1994, Gammage 2011, Head 1994, Langton 1998) have detailed and speculated on the relationships between Aborigines, Europeans, vegetation and landscape fire, revealing complex more-than-human entanglements with patterns of slippery, shifting agency. This research has highlighted gaps in both popular and academic understandings of human co-existence with landscape fire and the need for new understandings which blend social, cultural and scientific dimensions (Howitt 2014).

One area identified as deserving greater scrutiny relates to a perceived popular focus on human time-scales with a resulting neglect of the much greater temporalities and periodicities that influence landscape fire. For example, Franklin states that "It seems clear that the (human) social times of specific forest policies, management plans, fire events, and resource use are often out of kilter with the longer term ecological and glacial times over which ... trees and forests are active and influential" (2006:574). Temporal incongruities 
often arise because the focus of discussion, policy and practice is fixed on bushfire events and fire risks to human life and property rather than the wider entanglements within which these events and risks are situated (Griffiths 2009, Williams 2014).

Whilst the temporal framing of large-scale bushfires is frequently reduced in common parlance to a specific day, such as "Black Saturday" (Williams 2014:88), the spatial framing of fire events is often very broad in Australian popular culture. Although memorials may be located at specific sites, bushfires themselves are frequently named for the state (e.g. the Victorian bushfires) within which they occur (Williams 2014:88). Some researchers bemoan the spatial generalisations which dominate discussions, observing that in seeking to manage our relationships with landscape fire, we need to look for local solutions. For example, Griffiths (2009:35.5) suggests that:

"We need to abandon the idea of a national fire plan and develop ecologically, sensitive, bioregional fire survival strategies. We need to move beyond an undifferentiated, colonial sense of 'the bush' as an amorphous sameness with which we do battle, and instead empower local residents and their knowledge of local ecologies."

In addition to calling for greater recognition of the scalar dimensions of fiery entanglements, researchers have expressed concern that many people remain unwilling to relinquish the idea that humans cannot always control landscape fire. For example, Griffiths states that "It is hard for humans to accept that nature can overwhelm culture" (Griffiths 2009:35:1) and notes the use of military metaphors in fire-fighting which "conspire to make us believe that we can beat fire, somehow" (Griffiths 2009:35:4). Landscape fire is a particularly complex issue in that humans have greater capacity to influence not only the outcomes of events but also the nature of the actual event itself when compared to other 'natural' events such as earthquakes. However, this capacity in relation to landscape fire is still limited and variable; as observed by the Independent Hazard Reduction Audit Panel NSW (2012:6), "hazard reduction does not prevent or eliminate bush fires. Similarly, once a bush fire ignites and takes hold suppression operations will not always be able to extinguish it, particularly in extreme bush fire weather conditions." 
Understanding the nuances of this message can be challenging for new migrants to fire prone areas. Cooke and Lane report that, on finding that their understanding of ecological processes and land management "informed by prior urban lifestyles" has limited relevance in rural contexts, many landholders "turn to experiential learning" (Cooke and Lane 2015:43). Most of this learning takes place on property, and is dependent on observation of biophysical responses to human actions (2015:48). Cooke and Lane suggest that this, combined with a pre-existing desire to "be the autonomous custodians of a patch of land" (2015:46), may lead landholders to focus on very bounded spatial and temporal understandings of ecological processes. Major bushfire events have the capacity to brutally challenge such spatial and temporal bounding, but the periodicities of such events make property-based experiential learning about bushfire sporadic or unlikely. However, prescribed fire is more common and we suggest that this, combined with living with the threat of bushfire events, may have the potential to extend landholder horizons beyond property boundaries and beyond relatively short-term observations of biophysical responses to human actions.

\section{Methods}

This research was conducted in 2013 in Northeast New South Wales. Geologically, the area is dominated by the Mount Warning caldera formed around 20 million years ago. The valley is surrounded on the north, east and west by the Border Ranges National Park which is internationally significant ecologically, being part of the Gondwana Rainforests of Australia which were awarded World Heritage Status in 1986. Broad native vegetation formations include wet sclerophyll forest interspersed with sub-tropical rainforest in gullies and dry rainforest at lower altitudes and on steeper, drier slopes (Lennon 2012:3).

Historically, fire has been used to manage land in this area, initially by indigenous inhabitants from the Bundjalung language group (Lennon 2012:3) and then by European settlers. At other times landscape fire has been suppressed, for example, through the dispossession of Aboriginal people and as a result of pressure from National Parks and other groups, although fire is currently enjoying something of a revival with people of both Aboriginal and settler heritage using it to manage land. Along with this varied fire history, 
extensive timber extraction, saw milling and clearance for agriculture have resulted in fragmentation of the native vegetation and facilitated infestations of weeds, most notably Lantana camara and Ageratina adenophora.

This paper draws on data from two interviews, or conversations, held with each of six landholders before and after fire training workshops were conducted in the area. These landholders were chosen randomly from a list of potential workshop attendees who, at the time of the interview, had been managing land for around a decade or more. Previous research (see, for example, Eriksen and Prior 2011) suggests that after ten years landholders are more likely to be more positively disposed towards the benefits of both wildfire and hazard reduction burns than those who have more recently migrated to rural areas. Thus it was felt that in working with landholders who had managed property for ten years or more we would be more likely to develop understanding of the trajectories of landholder relationships with fire and Country.

The landholders interviewed range in age from their early forties to late sixties and have lived in the area from 2 to 50+ years. They represent a range of landholder experiences: Phil and Robert were raised on the land they are now farming; Martha and Laurie run a guesthouse on their property; and Kenny and Tom maintain their properties primarily for conservation and / or recreation. They also represent a range of income streams: Martha, Laurie and Robert are primarily dependant on their properties for their income but the other interviewees are not and one of these is an active participant in the informal economy. Two of the interviewees regularly conduct prescribed burns on their landholdings in order to reduce the risks of wildfire to people and property, to maintain or enhance biodiversity and / or to manage weeds. One of the other landholders intends to conduct a prescribed burn in the near future but the other three have no plans to do so. All of the landholdings are in an area of steep terrain and four of them border the National Park. Most of the conversations took place partly in the landholder's home and partly when walking or driving around the landholding. Rather than using a structured format, the aim was to elicit a conversational narrative (see Grele 1998) to allow landholders to identify and articulate issues of importance to them. Moving around the landholding brought direct interaction with soils, flora, fauna, topography, weather and so on for both researcher and 
landholder, allowing “...the lifescape of the methodology to overlay and seep into the lifescape of the farm, giving access to ... often more hidden, non-verbalized understandings" (Riley 2010:659). The total conversation time with each landholder was between 120 and 350 minutes.

Conversations were audio recorded and transcribed verbatim. Individual landholder stories were then created which focus on issues identified by the researcher as being of common interest to all landholders through multiple listenings to, and readings of, the interviews. Each is a seamless narrative constructed from actual quotes / stories told by a single landholder. Editing was restricted to facilitating ease of reading. Presenting research through narrative is not uncommon in disciplines such as Education (Knowles et al 2008, Knowles and Cole 2008) and Psychology (see, e.g., Howard 1991) and, as noted by Wylie (2005:237), "forms of narrative - memoir, montage, travelogue, ethnography - are being used both within and beyond academia as creative and critical means of expressing posthumanist philosophies of place". These narratives are often autoethnographic but alternative narrative approaches have been adopted. For example, Dare et al created a composite narrative drawn from multiple community engagements around plantation forest management, in the belief that doing so "enables the reader to embed themselves in the described situation, allowing the story to bring the key themes to life" (Dare et al 2011:1154). It is our belief that adopting a narrative approach, rather than relying solely on "static quotes", draws attention to the dynamic spatialities and temporalities associated with fiery entanglements.

The next section begins with the narrative of one of the landholders, Phil, who now farms part of the property he was brought up on and has extensive experience with fire, and continues by considering how the other landholders' stories and comments relate to Phil's narrative.

\section{Results and Analysis}

Phil's Story 
I've had experience with fire. Worked for Parks (the National Parks and Wildlife Service) down south, and fire was basically all we did. Wildfires, hazard reductions - that place is always on fire. Long before that, my father used to light fires off the back of a horse. We were all very pro National Park and we had grazing all through that area but we lost that, the National Park was all about rainforest conservation. And they didn't like fire incursions into their park and came down very hard on us about burning. There was a lot of talk about legal liabilities, and making fires stop at property boundaries is just impossible in this country.

Newcomers blew in to town. The way the Rural Fire Service (RFS) works - it's a social thing. If a person does a thing they don't like, he's in the out-group, not part of the team. So between Parks, the blow-ins and the RFS, the burning stopped. And we'd had 100 years or so of logging, so between the logging, the drought and no burning the forests were really degraded. You could see it in the trees, loaded with seed, dripping with seed, putting everything into reproduction. "We're close to death, this is our evolutionary sort of lottery. Put all the seed out. We're gonna win this one."

At the end of the drought (in early 2006) a series of dry storms came through - bang, bang, bang - lit all these fires, crowning and whatever. Wiped the slopes clean of the last 150 to 200 years, killed everything except the bloodwoods. Never seen anything like it. The fire went through brush box palm gullies that I would have thought would be completely wiped but three weeks later I went back up there and there's a bloody green shoot bursting out the top of a bangalow palm. And one of the greatest benefits of that fire was an enormous seedling recruitment of schlerophyll canopy species. Rainforest regeneration as wellsurprisingly.

It was amazing. It changed my ecological understanding of this area. You do not understand the evolutionary tolerances of these species until you see them go through something like that. And it really boils down to the fact that gene fixation for a lot of these species occurred hundreds of thousands of years ago. That's when the really major species ecology was fixed, in that extreme fire regime. You had low sources of ignition so you'd just get these catastrophic fires. You'll get aboriginal burning and other sort of disturbance going on but it's those events that occur infrequently that are absolutely profound. They set the structure 
for wet sclerophyll forest in this area. Define refugial boundaries between wet sclerophyll and rainforest.

Hard to get the RFS to see it that way. Too busy fire-fighting - not managing a process but locked in conflict. Locked in asset protection mode, they'd no sense that this might have been the most valuable ecological event in their lifetime. Hell, at the time even I thought it was a disaster. But you need to understand what you've got there. Extreme drought coupled with an absolute optimal recruitment event - extreme fire followed by five inches of rain. Could you ask for a better regeneration event? It's that coupling thing together, it's just been repeated through history for millions of years and we just wanna come along and disrupt the whole thing. Way I see it, nothing'll change until we get the fear out the way. We need fear - stops us doing stupid things - but we can't plan, can't manage, can't legislate based on fear. Especially not fear of something so elemental. And that's one of the things I've come to understand, that we really need to have long-term planning for these extreme wildfire events from an ecological objective.

Last ten years there's been a big turnaround on fire. Rampant Bell Miner Dieback's ${ }^{1}$ woken people up a bit. Parks have come round now - I'm burning again and I'm doing it together with Parks. I've got to admire them really, for changing their attitude. Anyway, I've no choice but to work with them, I've got a six kilometre boundary with the Park that climbs 300 metres in altitude and crosses a handful of gullies. It's totally artificial, there's no natural place for a fire to stop. Now fire comes into my land from the Park, I let it run and they do the same for me.

There's an awful lot of good intention out there, people want to give due respect to native plants and animals. The whole National Parks movement has been driven by that but the complex argument is missing. Locking areas up might be ok for refugial type environments but some areas are dependent on large-scale processes. Fire's a classic example. Those fire paths out of the alpine ash forests (in Victoria, Australia) have been going on since the year dot. The ecology of alpine ash is completely driven by the big fires, wouldn't exist without

\footnotetext{
${ }^{1}$ Bell Miner Associated Dieback refers to eucalypt dieback associated with psyllid infestation. This is frequently associated with high numbers of bell miner birds which, due to their aggressive territorial behaviour, drive away insectivorous birds that would otherwise control insect numbers (see http://www.bmad.com.au/about.html).
} 
them. I always thought that wasn't the way it works up here with the wet sclerophyll, but it is. And people think, "Oh, that's a lovely ridge, l'll get a beautiful view if I build there", right in the middle of a fire path. They completely change the fire trajectory for that side of the hill. And that fire path not only affects them, it affects where the fire's gonna go in future.

\section{Scalar Considerations}

Throughout this monologue Phil weaves stories which reveal a cluster of relationships operating across a range of temporal and spatial scales. Phil draws extensively on history and pre-history in his references to gene fixation "hundreds of thousands of years ago", Aboriginal burning, 100 years of logging, the decision by "Parks" to come "down very hard on" landholders who allowed fire to run into the National Park in the nineteen eighties and the severe drought of the early $21^{\text {st }}$ century. These issues were also referenced by the other interviewees. For example, Martha suggests that recent changes in vegetation may reflect the deep history of the area:

Martha: And the type of forest is constantly changing... Even Bell Miner Dieback - OK, it's exacerbated with the climate - but I still think that's part of the cycle. Because there's areas where the gums are dying because of bell miners but there's rainforest coming up underneath (our italics).

A more recent influence on landscape fire was mentioned by all of the interviewees. During the late $19^{\text {th }}$ to early $20^{\text {th }}$ Century, this area was extensively logged by Europeans, with hoop pine and cedar being the most sought after species (National Parks 2001). This had implications for the species composition and structure of the forest and all of the research participants believe that this impacted heavily on fire relationships in the area. Laurie explains:

Laurie: I mean if we were able to go back a hundred and fifty years and prevent any weeds coming into this area and we were able to prevent the degree of logging that was carried out over that period then we would have a totally different environment - one which would not be so susceptible to fire. 
Most of the landholders appeared less certain about the relationship between fire and the Bundjalung Aboriginal people, whose home was in these forests before, during and after the period of logging. Phil has a keen interest in indigenous fire management and spends time researching and reading around the subject. Of the others, all believe that indigenous peoples burned land in some parts of Australia, however whilst Laurie and Martha think it highly unlikely that this area had been burned by Bundjalung people because it was a "moister rainforest type area", the others are open to the possibility but have no firm belief either way. All agree that settler farmers had a substantial impact on the trajectory of fire in the area, due to government policies which gave financial incentives to farmers who cleared land. Clearing was frequently achieved through burning, and long-term residents of this area indicate that burning continued to be a regularly used method of land management until the creation of the National Park in the mid-1980s. At this time, the decision was made by "Parks" to cease burning in the area and to encourage others to do so. Whilst there has since been another reversal of policy, with staff now burning the National Park again, many landholders believe that the earlier decision has had profound consequences for the trajectories of landscape fire in the area. Robert complains that the cessation of burning caused the regrowth of shrubby vegetation such as Crofton weed (Ageratina adenophora) and Lantana (Lantana camara) to such an extent that:

Robert: (Human prescribed) fire's a thing of the past. To be honest, it's just nearly impossible. If it got away and got up on that mountain, there's nothing to stop it now. It'd burn down everybody's place...

These landholders, then, show awareness that landscape fire events are temporary phenomena in the life of a much larger entanglement that operates across a range of temporal scales. Moreover, they appear to recognise the disconnect between the timescales commonly focused on by humans in response to fire events and the much longer biophysical timescales influencing landscape fire, as shown, for example, by Phil's comments on the need for planning for extreme wildfire events to recognise ecological time-scales.

These landholders also show awareness that the influences on landscape fire 'events' operate across a range of spatial scales. For example, Robert describes a recent incident in which he set a fire on his land. On his way back to his house he had a brief discussion with a 
tourist who was concerned that the fire would burn into the National Park. Despite being reassured that the fire "can't go nowhere", the man later phoned the fire brigade and Robert was then contacted:

Robert: So I get back up the hill, and there's the brigade from (W) and another one from (W) and they couldn't even find the smoke. This fella here on the hill rang triple zero on his mobile phone. And the brigade have come a hundred ks, they've gotta put it out. What chance you got? Soon as they see the smoke they ring the fire brigade and that puts pressure on everybody, right?

Robert acknowledges the complexities of this situation. He explains that people who are unfamiliar with this area "panic soon as they see smoke" but they don't understand local humidity, wind speed and fuel loads in the same way that he does. He acknowledges the pressure on the fire brigades that have come 100 kilometres and need both to justify their journeys and to ensure that they will not have to return to the scene because of a genuine need to do so. Other participants also mentioned the impact of issues relating to the spatial distribution of fire brigades, lamenting the days when fires were managed by local landholders coming together to investigate and, if necessary, act upon any reports of unexpected smoke without the need for intervention from outside the area.

Robert returns to the theme of spatial complexities when expressing frustration about the difficulties of implementing locally appropriate practice under the law in a state that covers more than 800000 square kilometres. He explains that:

Robert: It just gets dry enough that you could get a burn and we've got a total fire ban. I know there's areas down south that need it but it's too broad. They bring in a total fire ban for Northern New South Wales and we can't get a burn to happen.

Robert is not alone in drawing attention to the need to find local solutions to co-existing with fire, with all landholders questioning the wisdom of state-wide regulations. Phil also emphasises the need to localise human action when complaining that there was too much discussion of generic principles rather than site-specific issues during a fire-management course he recently attended. All of the landholders describe the "impossibility" of containing landscape fires at property borders, showing awareness of the need to develop landscape 
scale strategies for co-existing with fire and discussing the complexities of reaching agreement on such strategies in view of the number and heterogeneity of landholders involved.

Whilst recognising the need for local strategies, landholders do extend their understanding of influences on landscape fire beyond the parochial, for example when speaking of the "dependence" of the alpine ash forests on "large-scale processes". Robert draws in global scale issues when reporting on the impact of timber markets on the vegetation ("fuel") on his property. In the recent past, Robert logged and sold flooded gum (Eucalyptus grandis) from his property, however he is now struggling to find a market because the demand for local wood has "just about wound up at the moment." When asked whether local subdivisions and accompanying rural in-migrants might provide a market, Robert responds, "Ah, it's just all imported stuff" in the new houses. Competition from this cheap, imported wood makes it difficult for Robert to justify the time and cost of extracting trees and this has a consequent impact on the quantity and type of fuel on his property.

In speaking of co-existence with landscape fire then, landholders repeatedly reference complex entanglements which operate across a range of scales. Whilst calling for legislation and land management policy and practice to recognise the specificities of local situations, they also encourage greater recognition of the impact of large-scale regional and even global processes on landscape fire.

\section{Complexity and Control}

Despite their shared tendency to recognise the scalar complexities of human/fire/land relationships these landholders cannot be viewed as a homogenous group sharing a pure ontology. The main way in which they appear to differ is in the extent to which they draw attention to non-human agency beyond the role that it plays in supporting or thwarting their intentions. All landholders have intentions for their land, even if these are to leave it be', and at some point all of the interviewees evaluate fire in terms of its capacity to support these intentions, particularly in the context of the invasive plants lantana (Lantana camara) and Crofton weed (Ageratina adenophora). For example, Todd explains: 
Todd: Lantana will absolutely overrun a place in 5 years. If they get to the point where they say (prescribed fire's) got to be once every ten years or every 8 years, it's just too far apart to be used as a tool for weed control because the shit grows behind you as you kill it.

All of the landholders believe that fire could support their land management visions, subject to the right legislative, climatic and fire conditions, but for most landholders this is not the whole story. Phil is most explicit in acknowledging that the power of non-human agency extends far beyond relationships with humans. Indeed, Phil pushes humans to the periphery, explaining that "You'll get aboriginal burning and other sort of disturbance going on but it's those (wildfire) events that occur infrequently that are absolutely profound." In Phil's view, humans can certainly "disrupt" and "change" fire trajectories but ultimately non-human agency is more powerful, and positively so.

Like Phil, Robert has detailed scientific and experiential knowledge of the land; his 1500 acre property has been in the family for over a century. Although the language he uses is different, he is sympathetic to people who talk about biodiversity and knows "where they're coming from". However, Robert is far more inclined to reference non-human agency in terms of the extent to which it impedes or supports his intentions. For example, he states, "We used to burn (that paddock) years ago. It's a good paddock. Cattle used to be beautiful." He describes certain plant species as "rubbish" and his distress is clear when this "rubbish" expands in ways he deems inappropriate:

Robert: We can see it getting overgrown. It's a shame to see it going the way it has. Most of it's just Crofton weeds and rubbish... Country's got in a hell of a mess... Those people there with those blocks, they couldn't give a stuff what grows on it... Most of 'em you can't even walk over it.

These sentiments echo those of many Aboriginal people, for example, participants in Lesley Head's research who felt similarly challenged by "dirty country" (Head 1994:176) which limited access by foot and vehicle and access to game. Robert wants access across land which he sees as productive and fire offers a useful, if blunt and temperamental, tool through which to achieve these aims. Indeed, he describes fire as "our spraying machine." However, whilst he does talk about land management in terms of human control Robert is 
fully aware of the fragility of that control. Toggling between the agency of humans and other-than-humans, he expresses frustration that legal structures fail to acknowledge the complex relationships between fire, plants and humans that ebb and flow over time:

Robert: You can't guarantee - you can put in a fire break, you can do what you like with dozers and gear - but you can't put a thing in there to say, right, that's it, fire proof... in this country a brush box tree can burn for bloody six months. Fall over right at next door ${ }^{2}$ and you're still responsible. Even when you get a permit, it's your name on that permit.

Like Robert, Kenny has also been dependent on manipulating plants in order to earn a living, training as an ornamental horticulturalist and working in a large European city before buying his 100 acre property. Kenny speaks about fire and land management as "a game of snakes and ladders"; a game in which his own desires and intentions are constantly being challenged by "natural" forces. The game is something to be experienced rather than viewed as a source of frustration. The fact that he will rarely, and only ever briefly, be in control of the direction taken by fire on his property appears to be accepted by Kenny as inevitable. This position is shared by Tom who observes that, "We don't control fire - we change it but we don't control it."

Martha believes that there are benefits to fire, particularly in terms of reducing the physical labour required to reduce the growth of unwanted vegetation. Her husband, Laurie, is more inclined to see fire primarily as a force that thwarts his intentions. He describes a fire in 2001 that "took out" 300 acres of their property as "...a disaster". Laurie is fearful of the power of fire. He explains that they have:

Laurie: 1700 metres of boundary on the west side with the National Park. No fences, no containment lines, so any fire that we are party to - or from our property that goes into the National Park - potentially can destroy insurmountable areas of forest.

Laurie does recognise that landscapes are "constantly evolving" however he maintains attachments to specific plants and plant configurations and sees fire primarily as damaging, not creative.

\footnotetext{
${ }^{2}$ i.e. into a neighbour's garden and start a fire
} 
Overall, these comments by landholders are consistent with the belief that humans are just small parts of a complex entanglement in which the locus of control is constantly, and sometimes unpredictably, changing. Even Robert, who refers to fire as his "spraying machine", accepts that it is temperamental and will make its own accommodations within the landscape. Phil embraces the power of the non-human to prevail, whilst Laurie believes fire to be an enemy that we should seek to tame albeit that our efforts will frequently be futile. For others, including Kenny who plays "snakes and ladders" with non-human actors, the lack of central control just is. In this way he appears to share Ingold's view that, in the end, "the world will go its own way regardless" (Ingold 2006:18).

This understanding of the locus of control does not mean that these people believe they have no influence at all on the trajectory of fire in the landscape but it does guide acceptance of their own limitations. For example, several interviewees mention that in the highly productive areas of Northern New South Wales, it is not actually possible to maintain fuel at levels that would really minimise the risk and potential damage of fire across an entire property. Laurie states that he and Martha are "just doing what we can, given what we have both financially and physically". These landholders recognise that, to a large extent, where and when fire starts and how it runs is dependent on relationships of such complexity that humans can only comprehend them as chance. A slight shift in wind direction, the forecast rain that doesn't come, the subdivision that offers no break to a fire, the planning decision that allows a house to be built on the ridge and the fact that the emergency services did not let the last wildfire run were each cited by one or more of these landholders as contributing to the trajectory of landscape fire in the area. Thus these landholders see no value in blaming individuals when this huge, unwieldy entanglement bursts into human consciousness by threatening (and sometimes consuming) land, structures or lives. As Phil states:

Phil: $\quad$ Fire sits within a social context that's outside of the farmer's control. Farming is just part of this whole social process that's part of a colonial domination of the landscape. To say the farmer has more responsibility beyond a simple statement of involvement is kind of stupid. It's like we've set up all this land as farming, as a way of extracting value out of the landscape, and then you're gonna blame the person who's got his name on the deeds if 
anything goes wrong? Then you don't really understand what the hell you were doing setting up agriculture in these contexts in the first place.

\section{Living the Questions}

Immersion in fire-prone environments influences not only the understandings of landholders but also the ways in which they come to 'know' land and fire. Phil explains that landholders get information about the environment, “...just by being around, going about your business. It's no labour, it's just what happens," and this accords with other research on learning styles of long-time landholders (Armitage et al 2009, Knapp and FernandezGimenez 2009). Our research suggests that, for landholders new to managing land, immersion in rural environments encourages a shift away from a tendency to rely on knowledge gained through more cerebral learning in urban social or political contexts towards learning through physical engagement and experimentation. For example, Kenny describes his shift from being an "extreme greenie" whose land management was heavily influenced by his identification with a particular community, towards a more adaptive approach in which he views land management as "an organic type of process, not black and white... a work in progress..." Martha explains that when she bought her property she was an observer - a painter - who believed that "the bush could look after itself". Over time, however, she came to question this belief and her relationship with her land became much more active as she responded to Lantana camara incursions across paths and tracks, feral cats killing native birds, wind-blown trees blocking creeks and, particularly, a bushfire. Learning became a process which was no longer dominated by book-learning or observation but by practical, physical interaction with the land. For Martha and other interviewees, the process of 'dwelling' in these environments transforms not only the knowledge and skills of landholders but also the ways in which they come to learn.

This supports findings by Cooke and Lane that there is a transition towards experiential learning when amenity migrants first move to rural properties (2015:48). Cooke and Lane conclude that because the learning process is "bounded by experience in the property space", learning can become "resistant to information and advice that (comes) for (sic) outside this space" (2015:50). However, we suggest that, in the context of landscape fire, 
the landholders in our research continue to seek information from human and non-human beings beyond property boundaries. As described above, all of the landholders mentioned the influence of large-scale temporal and spatial processes on contemporary fire trajectories, having being provoked by experiences on their own properties to gather information through physical interaction with, observation of and reading about the wider environment. Furthermore, all of the amenity in-migrants (Martha, Tom, Laurie and Kenny) repeatedly referenced information passed on to them from landholders more experienced with fire in the area, which they appear to review in a spirit of constructive criticism, rejecting parts and retaining others in the context of knowledge gained through other sources. Thus, whilst there are definite shifts in the balance of information from different sources, for example, from cerebral approaches to physical engagements, and from advice from 'green' or other communities to that obtained from local landholders, these inmigrants have not become closed to information from beyond their property boundaries. We suggest, then, that prescribed fire, bushfire and the threat of bushfire forces considerations of wider relations, pushing landholders to extrapolate from their propertybased learning to develop a deeper appreciation of the much larger scale considerations involved in fiery entanglements.

\section{Discussion}

Overall, the landholders interviewed for this research appear to be across Howitt's recommendation "to consider the need to rescale questions of coexistence with fire" (2014:61). All acknowledge the links between landscape fire and current, historical and prehistorical events from, for example, the breeze that carries fire from a road to the top of a hill in a couple of seconds, through the logging of the forest a century ago and the actions of National Parks decades ago, to the "gene fixation" that occurred hundreds of thousands of years ago. Whilst catastrophic events certainly focus attention on fire, these landholders maintain awareness of the rhythms and periodicities beyond these events and live their relationships with fire long before and after the flames are licking at smoke-darkened skies. Similarly, landholders recognise the range of spatial scales influencing landscape fire. They are frustrated by the lack of locally driven nuance in legislation, education and practice 
around fire: Robert bemoans the lack of differentiation in fire policy and legislation between northern and southern NSW, whilst Phil feels disenchanted by the lack of specificity in fire education programs. However, they also recognise that influences on fires can be spatially displaced, for example through global timber markets.

The views of these landholders are also broadly consistent with an understanding of humans as just small parts of fiery entanglements in which the locus of control is constantly, and sometimes unpredictably, changing. In this sense they may be seen to share the views of Cohen and Trigg (2013:84) that:

Humans are not lonely actors or masters of the ecosystems they inhabit. Human relationships with active materialities engender complicated narratives of living together in a difficult world, one in which the future may not be easy to discern but the prospects are numerous: an ethics of composition rather than imposition.

Howitt suggests that the most challenging issue in fire management is that of failure to coexist and asks "How do we know if we are failing to adapt - except retrospectively in the wake of catastrophe?" (2014:63). But our research suggests that these landholders who have lived on the land for more than a decade consider that what is catastrophic for individual human beings may not be catastrophic for the wider landscape. They believe that much of the biota of Australia has been primed over millennia to appreciate and be nourished by fire (Williams 2014:91). They do acknowledge that much can be done to reduce the risk of bushfire to humans, through localising fire legislation, improving fire science and warning systems, improving practice relating to subdivision, planning and property sales and educating newcomers on the benefits of "clean Country", and are clearly doing what they can to promote their own chances of survival. But, in speaking of "snakes and ladders", the fact that it's possible to "change fire" but not "control it", and the "impossibility" of making fires stop at spatial or temporal boundaries, these landholders judge that even their best efforts will never guarantee them the role of undisputed controller of fire. They accept that sometimes nature will overwhelm culture and that some human death and injury, and loss of property, is an inevitable if painful factor of coexistence. They recognise that living in fire-prone environments is inherently risky, and becoming more so as a result of changes in the physical and social structure of their region. 
These conclusions may seem at odds with research done into community perceptions of fire. We suggest this may be for two reasons. Firstly, much of the academic research and all of the high profile Royal Commissions into community "perceptions" of fire are conducted as post-mortems following major bushfire events. At this time people are grieving and feelings are raw, and the research frequently focuses on how lives and / or property could have been saved. Secondly, our research deliberately focuses on landholders who have actively been managing land for more than a decade. Howitt (2014) suggests that the push for evidence demanded by scientific approaches to fire management has led to difficulties in living with uncertainty in our relationships with landscape fire. However, rather than, or in addition to, reading and listening to 'experts' on how to co-exist with the immanence of fire, our participant landholders have been impelled to physically engage with the land and develop skills of experimentation to adapt to the forces inherent in this dynamic situation. Over time, these engagements and experiments lead to reflection which ultimately shifts understandings of complexities and uncertainties.

Over recent years, attention has been brought to the diversity of rural communities and the failure of NRM policy, education and research to fully recognise this diversity (Agrawal and Gibson 1999). In the context of fire, Eriksen and Prior warn against assuming fixed distinctions between groups such as "'locals', 'tree-changers', weekend warriors', fire fighters', 'greenies' and 'rednecks', (as) the situation is more complex than that" (2011:619). The stories of our landholders, all of whom have managed land for a decade or more, support Eriksen and Prior's suggestion that some of the diversity within and between these groups depends on time spent living in fire-prone environments, with a common trajectory towards understanding fire as creative and complex. Time of immersion in these environments may help to explain why landholders may have very different views, for example, on the emergence and evolution of, and appropriate responses to, issues such as Bell Miner Dieback.

There are, however, differences in the conceptualisations of landholders which confound attempts to model a simple relationship with time. Engagement with fire and land management may differentiate between fit and healthy humans and those with more limited physical capabilities or chronic health conditions (see, for example, Tham and Bell 2008). Financial considerations may limit the receptiveness, activities and thus the 
opportunities for evolution of those in more marginal economic circumstances. Some landholders, whether commercial farmers or recent rural migrants, continue to strongly identify with particular human communities regarding what constitutes "responsible and moral" (Gill et al 2010:318, see also Gill 2014) use of their land. For example, notions of good farming and the symbolic value of particular land management practices (see Burton 2004) may influence receptiveness to messages from Country relating to fire.

Nonetheless, we argue that immersion in fire-prone environments encourages progression towards an understanding of the complex spatial and temporal dimensions of fire, and the uncertainties and paradoxes involved, and this would seem to support the suggestion of Griffiths that in developing strategies for co-existence with fire we need to "...empower local residents and their knowledge of local ecologies" (Griffiths 2009:35.5). The dynamic nature of this knowledge, and its evolution through the mutually entwined trajectories of humans, fire and land, has potential implications for interventions, policy and practice. For example, how might beginning with ideas of immersion affect both the nature and timing of interventions to develop local understandings of fire? And what might be the implications for inclusive governance (McLennan and Handmer 2014) across a range of fields, from emergency management of wildfire to management of wider fiery entanglements which include issues such as rural subdivision (Bond and Mercer 2014)?

\subsection{Conclusions}

In Australia, learning to co-exist with landscape fire has often focused on the science of fire and fire management, the logics of planning and response and the building of ever more complex resources and fire institutions. What may be obscured by these activities, and by much of the debate about fire, are the ways in which some settler Australians are learning to co-exist within fiery assemblages by experimenting and adapting to the brute force of fire and through the more gentle accretion of experience on Country. For these people, fire is transformative not only in the dramatic ways we commonly imagine but also in its ability to expand human understanding of temporalities, spatialities and issues of control. Thus, immersion in fire-prone areas has the potential to shift the nature of learning itself, encouraging landholders to physically engage with their land whilst simultaneously pushing 
their considerations of ecological processes beyond property boundaries and beyond shortterm observations.

Around the world, fire regimes are shifting and fire-prone environments are becoming increasingly densely populated. Our findings challenge views embedded within some aspects of fire management and planning which position the local as limiting and characterised by an absence of knowledge and awareness. This challenge is not through an uncritical celebration of the local, nor through an understanding of the local as a static body of knowledge. Rather it is through an enhanced appreciation of how localised spatial scales and broader temporal scales reside in and constitute each other through relationships with fire, producing knowledge, skills, and dispositions suited to living with the immanence and actuality of fire.

\section{References}

Agrawal A, Gibson C C, 1999, Enchantment and disenchantment: The role of community in natural resource conservation World Development 27(4) 629-649.

Armitage DR, Plummer R, Berkes F, Arthur RI, Charles AT, Davidson-Hunt IJ, 2009, Adaptive comanagement for social-ecological complexity Frontiers in Ecology and the Environment 7(2) 95-102 http://dx.doi.org.ezproxy.uow.edu.au/10.1890/070089

Bawaka country including Suchet-Pearson S., Wright S., Lloyd K., and Burarrwanga L. (2013) "Caring as country: Towards an ontology of co-becoming in natural resource management". Asia Pacific Viewpoint. 54(2): 185-197

Blake G, 2003, 'Managing the Matrix: A Plain Language Manual to Help you Manage your Bush.' (Reserve Design and Management: Hobart, TAS) http://www.publish.csiro.au.ezproxy.uow.edu.au/?paper=WF10148\#sthash.rujPVcQo.dpuf. Cited in Halliday L G, Castley J G, Fitzsimmons J A, Tran C, Warnken J (2012) Fire management on private 
conservation lands: knowledge, perceptions and actions of landholders in eastern Australia. International Journal of Wildland Fire 21 197-209.

Bond T and Mercer D, 2014, Subdivision Policy and Planning for Bushfire Defence: A Natural Hazard Mitigation Strategy for Residential Peri-Urban Regions in Victoria, Australia Geographical Research 52(1) 6-22

Burton R J F, 2004, Seeing Through the 'Good Farmer's' Eyes: Towards Developing an Understanding of the Social Symbolic Value of 'Productivist' Behaviour Sociologia Ruralis 44(2) 195-215

Cohen J J, Trigg S, 2013, Fire Postmedieval: a journal of medieval cultural studies 4(1) 80-92

Cooke B and Lane R, 2015, How do amenity migrants learn to be environmental stewards of rural landscapes? Landscape and Urban Planning 134 43-52. doi:10.1016/j.landurbplan.2014.10.006

Dare M L, Vanclay F, Schirmer J, 2011, Understanding community engagement in plantation forest management: insights from practitioner and community narratives Journal of Environmental Planning and Management 54(9) 1149-1168

Eriksen C, Gill N, 2010, Bushfire and everyday life: Examining the awareness-action 'gap' in changing rural landscapes Geoforum 41(5) 814-825

Eriksen C, Prior T, 2011, The art of learning: wildfire, amenity migration and local environmental knowledge International Journal of Wildland Fire 20 612-624

Flannery T, 1994, The future eaters: an ecological history of the Australasian lands and people (Reed Books, Chatswood, NSW, Australia)

Franklin A, 2006, Burning cities: a posthumanist account of Australians and eucalypts Environment and Planning D: Society and Space 24(4) $555-576$ 
Gammage B (2011) The Biggest Estate on Earth: How Aborigines Made Australia. (Allen and Unwin, Crows Nest, Australia)

Gill N, 1994, The Cultural Politics of Resource Management: the Case of Bushfires in a Conservation Reserve. Australian Geographical Studies 32, 224-240. doi: 10.1111/j.1467-8470.1994.tb00673.x

Gill N, 2014, Making Country Good: Environmental Change and Stewardship in Central Australian Pastoral Culture Transactions of the Institute of British Geographers 39(2) 265-277

Gill N, Klepeis P, Chisholm L, 2010, Stewardship among lifestyle oriented rural landowners Journal of Environmental Planning and Management 53(3) 317 - 334

Grele R J, 1998, Values and Methods in the Classroom Transformation of Oral History The Oral History Review 25(1/2) 57-69

Griffiths, T, 2001, Forests of Ash: An Environmental History (Cambridge University Press, Port Melbourne, Victoria, Australia)

Griffiths T, 2009, 'An Unnatural Disaster'? Remembering and Forgetting Bushfire, History Australia 6(2) 35.1-35.7

Halliday L G, Castley J G, Fitzsimmons J A, Tran C, Warnken J, 2012, Fire management on private conservation lands: knowledge, perceptions and actions of landholders in eastern Australia International Journal of Wildland Fire 21 197-209

Haynes CD (1985) The pattern and ecology of munwag: Traditional Aboriginal fire regimes in northcentral Arnhemland Proceedings of the Ecological Society of Australia 13 203-214

Head L, 1994, Landscapes socialised by fire: post contact changes in Aboriginal fire use in northern Australia, and implications for prehistory Archaeology in Oceania 29(3) 172-181 
Howard G S, 1991, Culture tales: a narrative approach to thinking, cross-cultural psychology, and psychotherapy American psychologist 46(3) 187-197

Howitt R, 2014, Coexisting with Fire? A Commentary on the Scale Politics of Adaptation Geographical Research 52(1) 61-64

Hsu M, Howitt R, Chun-Chieh C, 2014, The idea of ' Country': Reframing post-disaster recovery in Indigenous Taiwan settings Asia Pacific Viewpoint 55(3) 370-380.

Independent Hazard Reduction Audit Panel, 2012, Enhancing Hazard Reduction in New South Wales: Discussion Paper. State of New South Wales through the Ministry for Police and Emergency Services.

Ingold T, 2006, Rethinking the Animate, Re-Animating Thought Ethnos 71(1) 9-20

Ingold T, 2008, Bindings against boundaries: entanglements of life in an open world Environment and Planning A 40(8) 1796-1810

Jones R ,1969, Fire-stick farming Australian Natural History 16 224-228

Knapp C N and Fernandez-Gimenez M E, 2009, Knowledge in Practice: Documenting Rancher Local Knowledge in Northwest Colorado Rangeland Ecology and Management 62(6) 500-509 Knowles J G, Cole A L (Eds.), 2008, Handbook of the Arts in Qualitative Research (Sage, London) Knowles J G, Promislow S, Cole A L (Eds.), 2008, Creating Scholartistry: Imagining the Arts-informed Thesis or Dissertation (Volume 4, Arts-Informed Inquiry Series) (Backalong Books, Halifax) Langton M, 1998, Burning Questions: Emerging environmental issues for Indigenous peoples in northern Australia Darwin, NT: Centre for Indigenous Natural and Cultural Resource Management, Northern Territory University. ISBN 9781876483067 
Lockie S and Higgins V, 2007, Roll-out neoliberalism and hybrid practices of regulation in Australian agri-environmental governance, Journal of Rural Studies, 23(1) 1-11

http://dx.doi.org/10.1016/j.jrurstud.2006.09.011.

Maclean K, 2009, Re-conceptualising desert landscapes: unpacking historical narratives and contemporary realities for sustainable livelihood development in central Australia Geojournal 74 451-463

McLennan, B J, Handmer J, 2014, Shared Responsibility: A New Way Forward? Bushfire CRC Fire Note 128 retrieved 19 July 2014 from http://www.bushfirecrc.com/resources/firenote/sharedresponsibility-new-way-forward

Miller AM and Davidson-Hunt I, 2010, Fire, Agency and Scale in the Creation of Aboriginal Cultural Landscapes. Human Ecology 38 401-414

National Parks, 2001, Border Ranges National Park, http://www.tropicalnsw.com.au/nationalparks/border.html)

Pyne S, 1998, Burning Bush: A Fire History of Australia Seattle: University of Washington Press Riley M, 2010, Emplacing the Research Encounter: Exploring Farm Life Histories Qualitative Inquiry 16(8) 651-662

Rilke R M, 1993 Letters to a young poet (Norton, New York)

Russell-Smith J, Craig R, Gill A M, Smith R, Williams J E, 2002 (Eds), Australian fire regimes: Contemporary patterns (April 1998-March 2000) and changes since European settlement. Australia: State of the Environment Second Technical Paper Series 2 (Biodiversity). Department of the Environment and Heritage, Canberra

Tham R, Bell T, 2008, Bushfire Smoke and Public Health Bushfire CRC Fire Note 128 retrieved 20 July 2014 from http://www.bushfirecrc.com/sites/default/files/managed/resource/fire-note-21.pdf 
Vaarzon-morel P and Gabrys K, 2009, Fire on the horizon: contemporary Aboriginal burning issues in the Tanami Desert, central Australia GeoJournal 74(5) 465-476.

Verran H, 2002, A Postcolonial Moment in Science Studies: Alternative Firing Regimes of

Environmental Scientists and Aboriginal Landowners Social Studies of Science 32(5-6) 729-762

Victorian Bushfires Royal Commission (2010) The 2009 Victorian Bushfires Royal Commission Final Report (Parliament of Victoria, Australia) ISBN 978-0-9807408-1-3

http://www.royalcommission.vic.gov.au/Commission-Reports/Final-Report.html

Williams S, 2014, Different Ways of Knowing How to Coexist with Fire Geographical Research $\mathbf{5 2} 55$ 57

Wylie, John (2005) A Single Day's Walking: Narrating Self and Landscape on the South West Coast Path. Transactions, Institute of British Geographers, 30:2, 234-237. 